\title{
CORRESPONDENCE
}

\section{Progress in 1979 on the Nomenclature of Pyroclastic Materials}

SIR - A meeting of the IUGS Subcommission on the Systematics of Igneous Rocks took place in Padua, during May 1979, under the chairmanship of Professor A. Streckeisen (Berne), and was attended by F. Chayes, USA, A. Dudek, CSSR, Mme S. V. Efremova, USSR, A. M. Goodwin, Canada, M. J. Le Bas, UK, R. W. Le Maitre, Australia, N. P. Mikhailov, USSR, P. A. Sabine, UK, R. Schmid, Switzerland (Secretary), K. Smulikowski, Poland, Mme V. Széky-Fux, Hungary, M. E. Teruggi, Argentine, B. Zanettin, Italy, with the following also present: W. Duffield, USA, Gp De Vecchi, Italy, Mme E. Justin-Visentin, Italy, E. Piccirillo, Italy, H. de la Roche, France.

The meeting dealt principally with the nomenclature of volcanic rocks, and particularly the pyroclastic rocks which had been the subject of a questionnaire distributed on a world-wide basis. It was agreed that the classification of pyroclasts and pyroclastic deposits should be based on non-petrogenetic features.

Recommendations for the plutonic and volcanic rocks have previously been published (see Streckeisen, 1976, 1978, 1979; Sabine, 1974, 1978).

The following summarizes the recommendations on which there was substantial or complete agreement, although some minor points have still to be resolved, and some matters merit further discussion.

\section{Pyroclastic deposits and fragments: descriptive nomenclature and classification}

Pyroclasts. Subject to resolution of minor queries that have arisen since the meeting, the definition is likely to be based upon: "individual crystals, crystal fragments, glass and rock fragments generated by disruption as a direct result of volcanic action'.

- A bomb is a pyroclast with a mean diameter commonly exceeding $64 \mathrm{~mm}$. Its shape (ellipsoidal, discoidal or irregular) or its surface (e.g. 'bread crust' surface) indicates that it was ejected in a wholly or partially molten condition.

- A block is a pyroclast with a mean diameter exceeding $64 \mathrm{~mm}$ whose commonly angular to subangular shape indicates that it was ejected as a solid.

- Lapilli are pyroclasts of any shape, with mean diameters of 2-64 mm.

- Ash grains are pyroclasts with mean diameters of $\frac{1}{16}$ to $2 \mathrm{~mm}$.

- Ash particles (or dust particles) are pyroclasts with mean diameters smaller than $\frac{1}{16} \mathrm{~mm}$.

Unimodal and well-sorted pyroclastic deposits.

- Pyroclastic deposits are consolidated and unconsolidated assemblages containing more than $75 \%$ by volume of pyroclasts.

- Pyroclastic rocks are mainly consolidated pyroclastic deposits.

- Tephra is a collective term for mainly unconsolidated pyroclastic deposits.

- A pyroclastic breccia is a pyroclastic rock whose average pyroclast size exceeds $64 \mathrm{~mm}$ and in which angular pyroclasts predominate.

- An agglomerate is a pyroclastic rock whose average pyroclast size exceeds $64 \mathrm{~mm}$ and in which rounded pyroclasts predominate. If the clasts are welded it is called agglutinate.

- A lapilli-tuff is a pyroclastic rock whose average pyroclast size is $2-64 \mathrm{~mm}$.

- A tuff (or ash-tuff) is a pyroclastic rock whose average pyroclast size is less than $2 \mathrm{~mm}$.

- A dust-tuff (or fine ash-tuff) is a pyroclastic rock whose average pyroclast size is less than $\frac{1}{18} \mathrm{~mm}$.

The granulometric classification of pyroclasts and of unimodal well-sorted pyroclastic deposits is shown in the accompanying Table 1.

Tuffs and ashes may be divided according to the composition of their fragments as shown on Figure 1.

Polymodal or poorly sorted pyroclastic rocks containing pyroclasts of more than one dominant size fraction should be named using an appropriate combination of terms, e.g.

- ash-lapilli tuff (lapilli > ash),

- lapilli-ash tuff (ash > lapilli), 
tuff, laharic ash-lapilli tuff, rhyolitic crystal tuff, etc. The terms may also be replaced by purely genetic terms such as 'air-fall deposit', 'base surge deposit', etc., whenever it seems appropriate to do so.

The granulometric size limits of $\frac{1}{16}$ and $64 \mathrm{~mm}$ have to be regarded as provisional numbers as long as an international agreement on granulometric divisions of sedimentary rocks is lacking. When in future such an agreement is achieved it might be necessary to modify them so that they will fit appropriate sedimentary size limits.

\section{Epiclasts and epiclastic deposits}

- Epiclasts are crystals, crystal fragments, glass and rock fragments that have been liberated from a pre-existing rock by weathering or erosion and transported by gravity, air, water or ice.

- An epiclastic deposit is a consolidated or unconsolidated aggregate of epiclasts.

- An epiclastic rock is a mainly consolidated epiclastic deposit.

The nomenclature and classification to be utilized in naming mixed pyroclastic-epiclastic rocks is shown in Table 2.

Table 2. Terms for mixed pyroclastic-epiclastic rocks

\begin{tabular}{|c|c|c|c|}
\hline pyroclastic* & mixed pyroclastic-epiclastic: tuffites & epiclastic & grain size $(\mathrm{mm})$ \\
\hline $\begin{array}{l}\text { agglomerate, } \\
\text { pyroclastic breccia }\end{array}$ & \multirow[t]{2}{*}{$\begin{array}{l}\text { tuffaceous conglomerate, } \\
\text { tuffaceous breccia }\end{array}$} & \multirow[t]{2}{*}{$\begin{array}{l}\text { conglomerate } \\
\text { breccia }\end{array}$} & \multirow[t]{2}{*}{64} \\
\hline lapilli-tuff & & & \\
\hline \multirow{2}{*}{ (ash-tuff) } & tuffaceous sandstone & sandstone & \multirow{3}{*}{$\begin{array}{l}\frac{1}{16} \\
\frac{1}{256}\end{array}$} \\
\hline & tuffaceous siltstone & siltstone & \\
\hline fine & tuffaceous mudstone, shale & mudstone, shale & \\
\hline
\end{tabular}

Glossary

A comprehensive glossary of all names applied to plutonic, hypabyssal and volcanic igneous rocks is to be prepared by the Subcommission under the editorship of Dr R. W. Le Maître (Melbourne, Australia).

Discussion also took place on chemical classification (where modal data are not obtainable) and on the subdivision of the andesite and basalt groups, but firm recommendations are not yet agreed.

\section{References}

Sabine, P. A. 1974. How should rocks be named? Geol. Mag. 111, 165-76.

Sabine, P. A. 1978. Progress on the nomenclature of volcanic rocks, carbonatites, melilite-rocks and lamprophyres. Geol. Mag. 115, 463-6.

Streckeisen, A. 1976. To each plutonic rock its proper name. Earth-Sci. Rev. 12, 1-33.

Streckeisen, A. 1978. Classification and nomenclature of volcanic rocks, lamprophyres, carbonatites and melilitic rocks. $N$. Jb. Miner. Abh. 134, 1-14.

Streckeisen, A. 1979. Classification and nomenclature of volcanic rocks, lamprophyres, carbonatites and melilitic rocks: Recommendations and suggestions of the IUGS Subcommission on the Systematics of Igneous Rocks. Geology 7, 331-335.

\section{J. LE BAS}

Department of Geology

University of Leicester

University Road

Leicester LE1 7RH

\section{P. A. SABINE}

Institute of Geological Sciences

Exhibition Road

London SW7 2DE 
